\title{
胸椎黄色勒帯骨化に関する電顕的観察
}

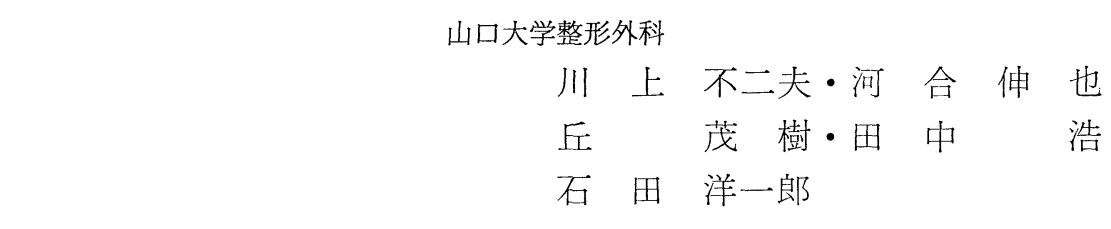

\section{Scanning and Transmission Microscopic Observation of Ossification of Thoracic Ligamentum Flavum}

by

\author{
Fujio Kawakami, Shinya Kawai, Shigeki Oka, \\ Hiroshi Tanaka and Yoichiro Ishida \\ Department of Orthopaedic Surgery, Yamaguchi \\ University School of Medicine, Ube.
}

\begin{abstract}
We observed thoracic ligamentum flavums which had been surgically removed, by use of a scanning electron microscope and transmission electron microscope. They were from 8 cases of ossification of thoracic ligamentum flavums and 9 cases of spinal canal stenosis or spinal tumors with no other ossification in roentgenograms for the control. These specimens were further observed by Toluidine blue staining and Van Gieson staining. In the case of ossification of the thoracic ligamentum flavum, close to the site of ossification, various degenerative changes were observed such as wavy pattern of elastic fibres, increase of chollagen fibres, irregular patterns, and appearance of oval and rosen-shaped granular particles. Nearer the site of ossification, appearance of chondrocyte and calcification of marix were observed. At the site of ossification, Haversian systems with osteogenecity were observed. These findings could show that ossification of thoracic ligamentum flavum may be the result of a course of endochondral ossification. We discuss more about the course of ossification from the viewpoint of degeneration of ligaments.
\end{abstract}

\section{はじめに}

靶帯骨化の原因につき, 生力学的機序, 内分泌学的 因子，遺伝的素因等の観点から解明の努力がすすめら れている. 当教室では，乙れまで走查電子顕微鏡を利 用するととにより，その三次元的形態から骨化過程の 解明をすす女てきた，今回，走査電顕に加え，透過電 顕による黄色勒帯骨化部及びその近傍の観察を加え, 骨化過程の検討を行った。

\section{対象及び方法}

対象は, 胸椎黄色勒帯骨化症 8 例, 対照として骨化 を有しない脊柱管狭窄症や脊髄腫瘍 9 例につき手術時 採取された黄色靯帯を脱灰グルタールアルデヒド固定
・アルコール脱水後走査型電顕観察用, 透過型電顕観 察用にわけ前者は臨界点乾燥, 金蒸着を行い, 後者は エポキシ樹脂置換, 加熱硬化処理後, ミクロトームで 得られた切片に䣷酸ウラン・クエン酸鉛により二重染 色を施し，それぞれ観察した. また，光顕用として Toluidine blue 染色, Van Gieson 染色し観察し た.

$$
\text { 結果 }
$$

これまでの丘1) の走査型電顕による観察では, 対照 群であるレ線上骨化を有しない黄色靯帯では, 椎弓間 部においては, 弾力線維は, 一般に規則正しく綐走 し，その太さは $3 \mu$ 前後である，一部に樹枝状に枝 分かれし, 隣接線維と連絡する microfibril が存在す 


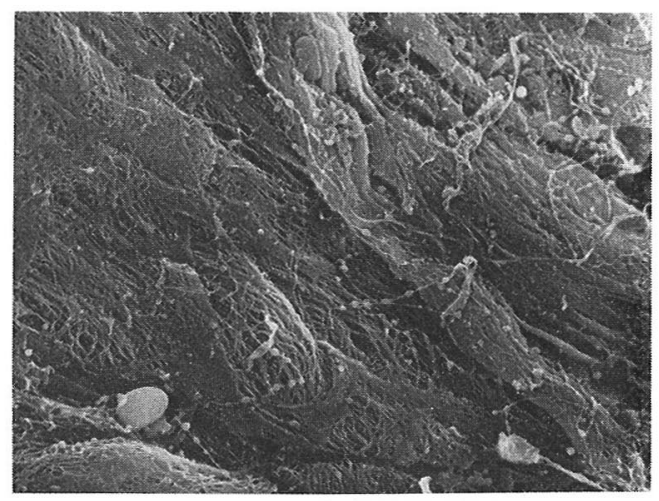

図 1 変性乙た弾力線維と紡錘形，鎖状物質の出現

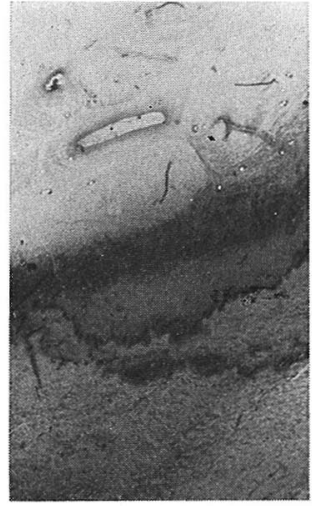

A

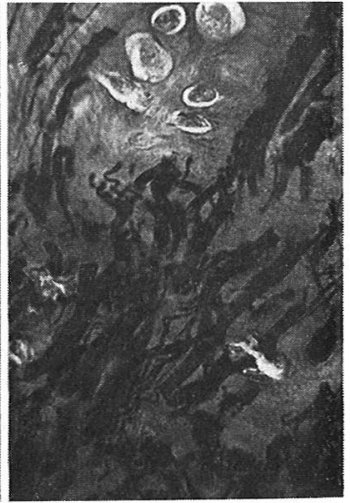

B
図2 A：骨化部及び骨化近傍(Toluidine blue 染色)

B：軟骨細胞の出現（Van Gieson 染色）

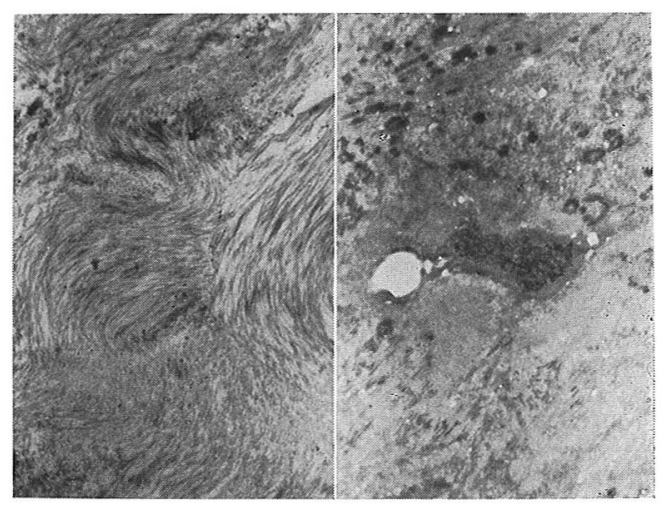

A

$\mathrm{B}$

図3 A：膠原線維の波状走行 $(\times 3700)$ B：骨細胞 $(\times 7000)$
る1). 椎弓付着部では, 弾力線維は, 骨付着部に近づ くにつれ，各線維間の境界が不明瞭となり，線維束を 形成しながら，層状構造を示す骨コラーゲンにある一 定の角度で侵入している．付着部に沿って毛細血管が 認められる，胸椎黄色靯帯骨化症においては，骨化部 に近づくにつれ，癒合傾向にある弾力線維の線維束は 大きな波状を呈し，枝分かれした microfibril の網目 状構造などの変性所見を認める．各線維間には紀錘形 ・鎮状の物質の出現を多数認める（図 1).

胸椎黄色鞋带骨化症の骨化部及びその近傍の Toluidine blue 染色では，骨化近傍に近づくにつ れ, 弾力線維の蛇行が著明となり, 弾力線維の数は減 少し，しだいに均質な間質成分が増加している，骨化 近傍では，細胞成分は，明瞭ではないが，Toluidine blue 飞均質に濃染する石灰化部分を認め，軟骨細胞 による基質の石灰化と考えられた．さらに近傍では， Haversian system 一移行する骨化部があり，骨芽 細胞の存在をうかがわせる(図 $2 \mathrm{~A}$ )。図 2 B は, 靯 帯付着部におけるVan Gieson 染色であるが，移行 部の弾力線維は, 枝分かれ, 蛇行し, 淡染した基質内 に大きな核を中心とする 円形の軟骨細胞が認められ る.

骨化近傍の透過電顕によると, Toluidine blue 染 色にて均質にみられる間質では，膠原線維が縦横に入 り乱れ，波状を呈して走行している. canaliculi は， 明嘹でないが，大きな核を有する紡鍾形の骨細胞を認 めた (図 $3 \mathrm{~A}, \mathrm{~B}$ ).

考

察

靱帯付着部及び 骨化近傍部において，軟骨細胞の 出現，周辺基質石灰化，骨細胞を経る Haversian system の形成を認め，黄色勒帯骨化は内軟骨性骨化 と推測できる. 1977 年酒勾2) らは骨標本による检討か ら, 黄色靱帯骨化は, 20 才以上に生じ, 年令と共に增 加する傾向があるととより変性を基盤とした生理現象 とも考えられるとした。 また, 1970 年 Scapinelli は， 組織に加わる牽引力, 圧迫力, 回旋力など局所的力学的 因子の変化により 細胞の metaplasia を生ずると説 いており，黄色靶帯骨化の力学的原因について，その 骨化近傍は興味深い観察部位之思われる．今回の骨化 移行部の観察において，骨化過程における初期像とし $て$, 膠原線維の增加, 弾力線維及び膠原線維の変性が 推測された. 変性部に動員される未分化間葉系細胞が 
軟骨細胞へ分化する過程が必要と思われ, 今回, 透過 型電顕を利用したが, 線維芽細胞, 軟骨芽細胞の骨化 近傍における同定は困難であったため, 軟骨細胞への 分化は証明され得なかった。

\section{結語}

1, 胸椎黄色靯帯骨化症 8 例, 対照として靶帯骨化 を有しない脊柱管狭窄症や脊䯣腫瘍 9 例につき, 手術 時採取された黄色靯帯を走查型及び透過型電顕を用い 観察した.

2. 骨化近傍に軟骨細胞を認め，黄色靶帯骨化症は 内軟骨性骨化であると推測された.

3. 透過型電顕による骨化近傍の観察を加え，骨化 過程の検討を行った.

\section{参 考 文 献}

1) Oka, S.: Scanning electron microscopic observation of ossification and calcification the ligamentum flavum. Arch. Jpn. Chir., 51:671-694, 1982.

2）酒匂 崇・他：黄色勒帯骨化の病態. 臨整外, 12: 368-376, 1977.

3) Scapinelli, R. : Observations on the mechanically induced differentiation of cartilage from fibrous connective tissue,

J. Pathol. 101: 85-88, 1970.
質 問 九州大学 杉岡 洋一

走查電顕, 透過電顕の外見から内軟骨々化が推定さ れたとのととであるが，骨化形態の観察にはむしろ光 顕レベルの観察で十分で，むしろ広い範囲の所見が得 られると思う。

軟骨基質の石灰化の状態に関して軟骨細胞の变性所 見，柱状配例などはどのようであったか.

\section{解 答背 山口大学 川上夫}

光顕レベルで軟骨細胞の出現を認めるならば，内軟 骨性骨化であると断言するととは容易であるが，勒帯 変性より骨化に至るまでの各細胞, 間質の変化をとら えたくて透過電顕による観察を加えた.

石灰化物質の出現については，同定していない。

質 問鹿児島大学 酒包崇
骨化機序の原因について演者は何を考えているか。

解 答出口大学 川上不二夫

骨化機序の原因は，慢性牽引による変性であると考 えている. その他の factor については, 現在のとて ろ解答できない。 